Journal of Universal Language 5

March 2004, 1-20

\title{
Aramaic as a Lingua Franca During the Persian Empire (538-333 B.C.E.)
}

\author{
Chul-hyun Bae
}

Seoul National University

\begin{abstract}
In the sixth century B.C.E. King Darius, king of the then-illiterate Persians, subjected the peoples from the Nile to the Indus. Old Persian, the language of the ruling Persian class, did not spread beyond the Zagros mountain because the rapidity of his empire's expansion outstripped the speed of its diffusion and intelligibility among the provinces of his vast empire. Furthermore, Old Persian script, newly created during the time of King Darius, was used only for special declarations, edicts, and proclamations of the king. Therefore, King Darius was forced to employ the contemporaneous languages of the ancient Near East for the record of his empire. For effective diplomatic communication among the provinces of the empire, Aramaic, a non-Iranian language, as a lingua franca, was chosen. It was a natural choice and a practical one: Aramaic was already widely spoken in the Levant, Egypt, and Western Iran and its alphabetic script was much easier to learn and write than the complicated Elamite or Akkadian cuneiform.
\end{abstract}

Keywords: pidgin, creole, lingua franca, Aramaic, Bisitun Inscription, Persian Empire 


\section{Introduction}

Although study of pidgin and creole languages started after Western European colonization in the fifteenth century C.E., it is certainly true that more existed in earlier times than the best-documented Pidgin Arabic and Lingua Franca (Holm 1988). A natural phenomenon like language contacts should have been occurred when people began to migrate to find food or a shelter in another region at the beginning of human existence on earth. Humans began to write only recently, at the end of 4th millennium B.C.E. in Mesopotamia and ancient Egypt.

Zyhlarz (1932) argued that the ancient Egyptian hieroglyph grew out of a trade language in Nile valley. That language was a language of traders, a pidgin which developed among several Afro-asiatic languages for the better communication around the Nile ports. There is ample evidence of well-organized internal trade in Egypt during the Archaic period ${ }^{1}$ and an examination of non-Egyptian materials shows that the exchange of goods with her foreign neighbors ${ }^{2}$ was extensive as well as intensive even in the earliest times.

Sumerians were speakers of the Sumerian language. The language is first attested in the earliest written records at the beginning of the 3rd millennium B.C.E. and became extinct by the early 2 nd millennium at the least, (Copper 1973, Lieberman 1977) but preserved as a language of scholars and cult through the end of the pre-Christian era. Sumerians at the threshold of Mesopotamian history adapted themselves most successfully to the cuneiform writing system. The transformation of this writing system that used language solely for an administration tool into one that could ade-

\footnotetext{
${ }^{1}$ Internal trade within Egypt shows that the place of origin of natural materials were found widely separated centers such as Sakkara, Abydos, and Hieraconpolis. For more detailed descriptions see Emery (1971).

2 For example, in transporting the produce of the quarries overland, the early Egyptians must have used sledges, for the cart was unknown to them. Mesoptamian carts, however, had been discovered in Egypt, which evinces international trading between Egypt and Mesopotamia.
} 
quately express natural language in a broad range of contexts was effected by the increasing use of rebus phoneticism to write grammatical affixes. Sumerian is an agglutinative language in which nouns take suffixes and verbs both prefixes and suffixes. Virtually no trace of these affixes can be found in the early archaic texts, but they begin appearing after 2900 B.C.E.

The earliest place names in Babylonia are not Sumerian (Jacobsen 1969). Therefore the early populations who named those places did not speak Sumerian. Based on perceived phonetic similarities, Lansberger (1974) associated a subgroup of these early place names with certain Sumerian words, dealing primarily with agriculture and crafts, which he saw as loanwords from the pre-Sumerian language of the place names, called by his Proto-Euphratic and Proto-Tigridic. The evidence of the non-Sumerian toponyms would make it quite difficult to posit the Sumerians as the indigenous population of southern Babylonia. Rather Sumeian excelled itself as a language of communication and trade among the indigenous languages.

In the 1 st millennium B.C.E., Aramaic functioned as a lingua franca in ancient Near East. Aramaic is the best-attested and longest attested member of the Northwest Semitic subfamily of the languages, which includes Hebrew, Phoenician, Ugaritic, Moabite, Ammonite, and Edomite. Aramaic was named after the ancient Arameans, among whom it originated; they lived in what is today Syria at the same time that the Israelites were establishing in Canaan in the late 2 nd millennium B.C.E. The language was spread, eventually becoming the language of government and international communication throughout the Near East, from the time of the Babylonians, who destroyed the Jerusalem temple in the sixth century B.C.E. and continued to extensively employed even after the coming of Greeks until the Arab conquest in the seventh century C.E, long after the Arameans themselves had disappeared.

The relatively small proportion of the biblical text preserved in 
an Aramaic original ${ }^{3}$ as well as isolated words and phrases in the New Testament ${ }^{4}$ belies the importance of this language for biblical studies and for religious studies in general, for Aramaic was the primary international language of literature and communication throughout the Near East from ca. 600 B.C. to 700 A.D, and was the major spoken language of Palestine, Syria, and Mesopotamia in the formative periods of Christianity and rabbinic Judaism.

The best-known writings in Aramaic were produced by other peoples. According to the Jewish tradition it was spoken by Adam ${ }^{5}$, and was probably the native language of Jesus, of numerous Talmudic rabbis, and of the third century religious innovator Mani, the founder of what we call Manicheanism. Moreover, a formidable body of literature, including many formative texts of both Judaism and Christianity, were written in or influenced by Aramaic. Aramaic was also used by the Nabateans, and Arab desert people who flourished around the time of Jesus, the later Syrian church, and the Mandaeans, a gnostic sect that originated closed to two thousand years ago in what is today southern Iraq. It continued to be used as a spoken language until now, albeit only in small pockets of Syria, Iraq, and Iran, as well as among Jews and Christians who have migrated to Israel and the United States from these regions.

Because Aramaic was a dominant language among the Jews of the first century Palestine, a wealth of important texts are written in it. Although Jesus' teachings survive only in the Greek New Testament, the Gospels provide ample evidence of Aramaic traditions surrounding him, and the language's influence can be felt in several other passages as well.

3 [Daniel] 2:4-7:28; [Ezra] 4:8-68, 7:12-26; [Jeremiah] 10:11; [Genesis] 31:47

4 An example par excellence is Jesus words on the cross. The Gospel of Matthew and Mark present the final cry of Jesus on the cross as follows: [Matthew 27:46] $\eta \lambda \iota \eta \lambda_{\imath} \lambda \varepsilon \mu \alpha \sigma \alpha \beta \alpha \chi \theta \alpha \nu \imath:$ [Mark 15:34] $\varepsilon \lambda \omega \iota \varepsilon \lambda \omega \iota \lambda \alpha \mu \alpha \sigma \alpha \beta \alpha \chi-\theta \alpha v \imath$. This phrase is an Aramaic translation of [Psalm 22:2] which was originally written in ancient Biblical Hebrew. In the time of Jesus, people spoke Aramaic because Hebrew died out 6 century B.C.E and replaced by Aramaic.

5 [Baraita Sanhedrin 38b] 


\section{Who are the Arameans?}

The term "Aram" was used in place names almost four thousand years ago; [Genesis] mentions places called Paddan-Aram and Aram-Naharaim. However, there are no references to the Aramean people themselves until the eleventh century, when the Assyrian ruler Tiglath Pilesar I encountered them on military expedition among the Euphrates. ${ }^{6}$ They had apparently established small, independent kingdoms, primarily in Syria, but extending as far east as the Persian Gulf. One Aramean ruler, named Adad-apla-iddina, even seized the Babylonian throne before coming under attack from other Arameans.

The Bible describes close connections between Israel's patriarchs and Aram, where they returned from time to time, ${ }^{7}$ usually find suitable wives. [Deuteronomy] even refers to the Israelites as being descended from "a wondering Aramean", 8 in a passage traditionally linked to Jacob, whose father-in-law Laban is called and Aramean in [Genesis] 31:20. Although scholars are not certain about the historical reliability of biblical statements about the patriarchs, such passages do demonstrate that the Israelites believed they were related to the Arameans.

During the period of Isarel's monarchy, the Aramean kingdoms of Zobah and Damascus joked with Israel for power and preeminence. The Bible reports that David defeated Hadadezer, the ruler of Zobah ${ }^{9}$, and that Solomon battled with Rezon, who had fled from Zobah and became king in Damascus. ${ }^{10}$

After the Israelite kingdom split near the end of the 10th century, regional control passed back and forth between Israel and Judah and

\footnotetext{
6 Tiglath-pileser I (1114-1076) campaigned from Assyria westward against an enemy ahlame armayya early in his region. A badly broken Assyrian Chronicle may imply that Arameans pressed into Assyria itself in his reign.

7 [Genesis] 24:1-10, 28:1-5

8 [Deuteronomy] 26:5

9 [2 Samuel] 8:3-10

10 [I Kings] 11:23-25
} 
Arameans, depending most often on whether the Israelite kingdoms were united or not. Sometimes they were subordinated to the Aramaeans; ${ }^{11}$ at others they were dominant. ${ }^{12}$ In the 9 th century, an alliance linking Damascus and Hamath with the Northern Kingdom as well as nine other countries was able to withstand the powerful Assyrian ruler Shalmaneser III (853 B.C.E); a decade later, the coalition fell apart and these same nations were defeated (841 B.C.E).

In the middle of the eighth century, Damascus entered into another alliance with Northern Israel, this time including the Phoenicians of Tyre. They tried to gain Judean support, but the king of Judah turned instead to Assyria, which was more than willing to intervene. As a result, the Aramean states were conquered by Tiglath-Pileser III, who claims to have destroyed "592 towns ... of the sixteen districts of the country of Damascus" (Pritchard 1969). He put several Aramean kingdoms under direct Assyrian control, including ultimately Damascus itself. The Arameans' political power thus came to an end; however, their language survived, ironically achieving a far wider presence that the people among whom it had originated.

\section{Periods from Old Aramaic to Official Aramaic}

Aramaic is attested over a period of almost 3,000 years, during which time there occurred great changes of grammar, lexical stocks, and usage. It has generally proved helpful for analysis to divide the several Aramaic dialects into periods, groups, and subgroups based on chronology and geography. Although no universally accepted scheme of such classificatory phases exists, and new discoveries regularly alter our picture. However, the general shape of outline is clear. ${ }^{13}$ Here I will introduce the earlier phrase of Aramaic dialects,

11 [I Kings] 15:6-20, 20:34; [II Kings] 10:32

12 [I Kings] 20:34, [II Kings] 13:25

13 A detailed survey and complete discussion of Aramaic dialects from Old Aramaic until now can be found in Beyer (1986). 
Old Aramaic and Official Aramaic.

\subsection{Old Aramaic (to ca. 612 B.C.)}

Aramaic began to appear as a language of the Arameans, at first in tribes and then city-states and petty kingdoms in Syria and Mesopotamia. This period witnessed the rise of the Arameans as major force in Ancient Near East history, the adoption of their language as an international language of diplomacy in the latter days of the Neo-Assyrian empire, and the dispersal of Aramaic-speaking peoples from Egypt to lower Mesopotamia as a result of the Assyrian policies of deportation. The scattered and generally brief remains of inscriptions on imperishable materials preserved from these times are enough to demonstrate that an international standard dialect had not yet be developed. The extra texts may be grouped into several dialects. $^{14}$

In the eighth century B.C.E. Aramaic became the lingua franca of the Assyrian empire, especially in the provinces "Beyond the River", which is the Euphrates. The Assyrians who used to employ rather complicated cuneiform writing system more than a millennium was replaced by the relatively simpler alphabetic Aramaic script, at first in the provinces where alphabetic writing was already in use and then in Assyria proper.

${ }^{14}$ Under Old Aramaic there are five branches of dialects: 1. Standard Syrian of 9-8th century B.C. around Aleppo, Syria; 2. Samalian, modern Zincirli, where dynasts of Neo-Hittite kingdom of Sam'al wrote their dedicatory inscriptions first in Phoenician, then in a local, highly idiosyncratic Aramaic dialect; 3. Fakhariyah, where a bilingual, Neo-Assyrian and Aramaic inscription was found on a statue; 4. Mesopotamian, whose texts consist of brief economic and legal texts and endorsements scratched on clay tablets. Not surprisingly, both Fakhariya and Mseopotamian dialects evidence a substantial amount of Akkadian influence; 5. Deil Alla, where an important but fragmentary text, painted on the plaster walls fo a cultic installation, recounts a vision of "Balaam, son of Beor," the Transjordanian prophet know from [Numbers] 22-24. 


\subsection{Imperial Aramaic (to ca. 200 B.C.)}

During this period Aramaic spread far beyond the borders of its native lands over the vast territories of the Neo-Babylonian and even larger Persian empires from Upper Egypt to Asia Minor and eastward to the Indian subcontinent. Unfortunately, only a remnant of the undoubtedly once vast corpus of administrative documents, records, and letters that held these empires together has been preserved, for such texts were written in ink on perishable materials, in sharp contrast to the more durable cuneiform clay tablets of earlier West Asiatic cultures.

The bulk of finds, however, is from Egypt, where dry climate led to the preservation of papyrus and leather along with the expected ostraca and stone inscriptions (Holm 1988, Teyssier 1959). ${ }^{15}$ The Aramaic "official" letters in the book of Ezra are almost certainly composed in Imperial Aramaic. The language and its epistolary style fit to this period.

\section{Aramaic as a Lingua Franca in the Persian Empire}

\subsection{What is a Lingua Franca?}

The earliest known text of a restructured variety of a European language spoken by sub-Saharan Africans is in a Portuguese poem published in 1516. Nergo Porteguese was identified as a pidgin. ${ }^{16}$

15 The major Egyptian finds are as follows: 1.papyrus archives of the Jewish military garrison at Elephantine; 2. The correspondence of the Persian satrap of Egypt, Arsames; 3. a packet of letters sent to family members residing at Syene and Luxor, discovered at Hermopolis; 4.Saqqarah, where a last 7th century papyrus letter from a Philistine king asking help of pharaoh against the king of Babylon; and legal and economic records on papyri and ostraca from the 5th and 4th centuries.

16 A pidgin, or contact language, is the name given to any language created, usually spontaneously, out of a mixture of other languages as a means of communication between speakers of different tongues. Pidgins have rudimentary grammars and 
Lingua is a pidgin, a trade language used by numerous language communities around the Mediterranean, to better communicate with each other whose language they did not speak. It is, in fact, the mother of all pidgins, seemingly in use since the Middle Ages and surviving until the nineteenth century, when it disappeared with hardly a trace, probably under the advent of the triumphant French language, leaving only a few anecdotal quotations in the writings of travelers or observers, an imperfect French, Lingua Franca vocabulary meant for settlers in the newly annexed territory of Algeria.

Lingua Franca had effectively only one verb form, corresponding to the Romance infinitive. It seems reasonable to suppose that speakers of one or the other Romance languages deliberately used this form in speaking to those who did not speak a Romance language, in order to relieve them of the chore of interpreting, and using, numerous verb suffixes $t$ the cost of the precision which these suffixes afford.

It may be noted, however, that Lingua Franca did develop a past and future tense when its heyday was over, a "golden age" which would be the seventeenth century, when there were so many captured Christian and Jewish slaves in Algiers. They probably used this trade language for local communication. These new tenses consisted of the past participle of Romance verbs for the past tense and the use of the word bisogno "need" for the future.

This suggests that Lingua Franca was in the process of being creolized, becoming more akin to a language spoken natively, with all the complexity. But this process was rudely interrupted by political changes that spelled the extinction of Lingua Franca in favor

restricted vocabulary, serving as contact languages. They are improvised rather than learned natively. As they develop, they can replace the existing mix of languages to become the native language of the current community (such as Krio in Sierra Leon and Tok Pisin in Papua New Guinea). This stage requires the pidgin to be learned natively by children, who then generalize the features of the pidgin into a fully-formed, stabilized grammar. When a pidgin reaches this point it acquires the full complexity of a natural language, and becomes a creole language. However, pidgins do not always become Creoles; they can die out or become obsolete. 
of French. The terminus ad quem of Lingua Franca is clear. It began to falter shortly after the arrival of the French in Algeria in 1830. The terminus a quo is much harder to ascertain. The Mediterranean was a great center of trade from earliest times and traders must have found some way of communicating.

\subsection{Various Terminologies for Aramaic as a Lingua Franca ${ }^{17}$}

Various terms appear in journal to refer to the Aramaic language during the Persian Empire (Folmer 1995). The terms are as follows: Imperial Aramaic, Official Aramaic, Standard Aramaic, and Egyptian Aramaic.

\subsubsection{Imperial Aramaic}

This term is found in a restricted sense to refer to the Aramaic during the Persian Empire or in a much broader sense to refer to the Aramaic using during the empires, Neo-Assyrian, Neo-Babylonian and the Achaemenid Persian. "Imperial Aramaic" a translation of German word "Reichsaramäisch" which was coined by Markwart (1927). He had in mind that this referred only to the language of the Persian Empire.

A serious argument against using this term is that the Aramaic during these empires was not a uniform language. Particularly the private letters found during this period show diversity of this language. Aware of this problem, Kaufman (1974) employ this term to refer to the dialects used for administration purpose in ruling great near eastern empires.

\subsubsection{Official Aramaic}

Ginsberg (1933-4) coined the term "Official Aramaic" to denote which was employed in the successive empires, Neo-Assyrian,

${ }^{17}$ Full treatment of this subject appears in Folmer (1995). 
Neo-Babylonian, and Achaemenid Persian Empire. Aramaic in these periods functioned as "official medium" for written document. This term is used by many scholars, either for broader or for restricted sense.

Fitzmyer (1979) is a proponent for broader sense of "Official Aramaic", which designates the language between 700-200 B.C.E. As I pointed out earlier, there are many documents which do not have an official character, which made this term misleading.

Greenfield (1978) used this term in restricted sense. Greenfield considered Official Aramaic as one of the dialects or styles of Aramaic of the Achaemenid period.

\subsubsection{Standard Aramaic}

This term was proposed by Krealing (1959) in order to avoid problems by employing "Imperial Aramaic" or "Official Aramaic". Unfortunately Krealing did not define linguistic characteristics of Standard Aramaic.

\subsubsection{Egyptian Aramaic}

Some scholars (Contini 1986) used this term to indicate the Aramaic material from Egypt. This terminology presumes the fact that most of Aramaic materiasl in this period were found in Egypt. This term is also misleading by ignoring the linguistic diversity of Egyptian Aramaic materials.

\subsection{Aramaic before Persian Empire}

Prior to Persian Empire, there were independent Aramean states in ancient Near East. Embracing the 10th-8th century B.C.E., many inscriptions were found at different places in Syria and southern Turkey. They reflect contemporary languages and dialects of the independent Aramean states, such as Damascus, the foremost Aramean state in the 9th-8th centuries, Hamath, Arpad and Sam'al 
(modern Zincirli). They antedate the period in which the territories in the western part of Syria were conquered by the Assyrians.

The most important texts were found in Afis (stele of Zakur king of Hamath and La'ash), Sefire (treaties of Mati'el king of Arpad with the king of $k t k$ ), Breij (Stele of Barhadad king of Damascus dedicated tpo Melqart), Hamath (graffiti), Arslan Tash (ivory with the name Hazael king of Damascus), all in Syria, and in Zincirli in southern Turkey (Hadad stele of Panamuwa I and stele of Panamuwa II). These texts are generally dated in the 9th-8th centuries B.C.E., prior to the Assyrian conquests. Recently, an Aramaic inscription was found on a basalt stone slab at Tell Dan, in northern Israel, dating from the 9th century (Biran \& Naveh 1993).

Among the mentioned texts, the inscriptions from the ancient Aramean king Ya'di (Sam'al), with its capital Zincirli, assum beyond any doubt a unique position. These texts, known as the Hadad and Panamuwa inscriptions, were written in a local dialect of Aramaic, often referred to as Samalian Aramaic, which has many archaic features and is quite distinct from other know dialects of Old Amamaic from this area.

Assyrian sources from the 10th century onwards make mention of several Aramean state within Mesopotamia proper (Malamat 1973). To date, however, only one fragmentary inscription is known, found in Tell Halaf (ancient Guzana) on Habur river in Upper Mesopotamia and dated in the early 9th century. Tell Halaf was the capital of the Aramaic dynasty of Bit-Bahiani. This state, however, succeeded, in remaining independent from Assyria only until 894 B.C.E. The inscription is generally believed to belong to the period of Aramean sovereignty.

It was during the 8th century B.C.E., that Aramaic emerged as lingua franca in ancient Near East. A particular variety of Aramaic became the administrative language of the Neo-Assyrian Empire. This first occurred in the western parts of the realm (Greenfield 1978, Naveh \& Greenfield 1984) and later to Assyria proper (Tadmor 1982). Evidence of Aramaic in the foreign contacts of the Assyrian appears in the well-known passage of II Kings 18:17-37 from 
the time of Hezekiah and Sennacherib (701 B.C.E).

The direct sources for the Aramaic of this period are Aramaic inscriptions on dockets and endorsements from 7th century Assyrian centers, namely Niniveh, Kalah (Nimrud), Assur and Guzana (Tell Halaf), a legal document of unknown provenance from the year 635, published by Bordreuil (Bordreuil 1973, Wesselius 1985a), a long letter on an ostracon found in Assur from ca. 650, which was sent from Babylon to Assyria and clearly attests for communication in Aramaic within the Assyro-Babylonian area between Assyrian high officials (Naveh \& Greenfield 1984: 115, Fales 1986).

The successors of the Neo-Assyrian rulers, the Chaldean rulers of the Neo-Babylonian empire (626-539), likewise used Aramaic for diplomatic purposes. Babylon in this period was strongly Aramaised and the Aramaic language seems to have replaced Akkadian as the main spoken language of the country (Naveh \& Greenfield 1984: 115, Greenfield 1982: 471). Unfortunately, the evidence of Aramaic texts from this period is scanty. Apart from Aramaic dockets from Babylonia, is mostly found in the West. ${ }^{18}$ The most important text, found at Saqqara is the letter of Adon, the king of Ekron, addressed to the Pharaoh which confirms the fact that Aramaic was used in this period as a lingua franca. Another important text is a tablet found in Syria published by Starchy (1960). An inscription with Aramaic text, found in Syria and published by Caquot (1971), possibly beongs to his period as well.

\subsection{Aramaic during Persian Empire}

Increasing use of Aramaic during the previous empires in Mesopotamia is generally considered to be the source and background for Aramaic as Lingua Franca within the Achaemenid period. Neo-Assyrian and Neo-Babylonian Empire. In this period Aramaic became the official language of the Achaemenid empire was used throughout the entire empire for all sorts of written communication.

${ }^{18}$ [Jeremiah] 10:11 
There is, however, no consensus concerning the origin of the official language of the Achaemenid period. The following two theories are found in the vast amount of literature on this subject (Kaufman 1974).

Firstly, the official language of the Achaemenid period has its origin in the Aramaic used for official and administrative purposes within the subsequent Neo-Assyrian and Neo-Babylonian periods. This theory was initiated by Ginsberg (1933) who maintains that the official language of all these periods is essentially the same. As a consequence of this theory, Official Aramaic of the Achaemenid period is seen as an offshoot of Old Aramaic. It is usually assumed that Assyrians became acquainted with Aramaic when they conquered Aramaic territories and deported their inhabitants. The subsequent question of whether this official language, then, was primarily influenced by Old Aramaic as found in the West or by Old Aramaic as found in the Habur and Balih regions. Dupont-Sommer assumes that it was the Old Aramaic language as found in inscriptions from Syria that was adopted by the Assyrians when they conquered these territories. According to Ginsberg (1933), however, Official Aramaic has its origin "somewhere east of the Euphrates; very likely in Assur itself and its immediate vicinity, that is to say, in a district east of the Tigris." It is noteworthy that this idea was proposed decades before the publication of the Tell Fekheriye inscription. Kaufman (1974) is a strong proponent of the region of the Habur and Balih rivers as the origin of the official language of the Achaemenid period, though he is aware that the language of Tell Fekheriye inscription is not the ancestor of Official Aramaic.

Greenfield is another advocate of the area of the Habur and Balih rivers as the source of Official Aramaic of the Neo-Assyrian period. This variety of Aramaic, which he calls "Mesopotamian Aramaic", became dominant in Syria as well with the spread of Assyrian influence there.

Secondly, the official language of the Achaemenid period originates within Official Aramaic as used in the Neo-Babylonian period, during which period Aramaic was probably a spoken language as well. Greenfield (1978), the proponent of this theory, claims that the 
basis of this language is that of Old Aramaic inscriptions from Syria, which he calls "Early Standard Aramaic," which has absorbed eastern features of morphology, syntax and vocabulary.

\subsection{Official Aramaic Attested among the Versions of the Bisitun Inscription}

The trilingual inscription of King Darius is carved on the rock of Mt. Bisitun, ${ }^{19}$ which is located about $30 \mathrm{~km}$ east of Kermanshah on the ancient royal road connecting Babylonia, Susa, and Ecbatana (modern Hamadan), which continues through central Asia to India. Out of massive mountain ranges along the road, Mt. Bisitun rises suddenly from the plain about $500 \mathrm{~m}$ high; its precipitous rock is ideal for engraving reliefs and inscriptions.

The Bisitun inscription of King Darius (DB) is best known for its role as the cuneiform Rosetta stone, which played a vital role in deciphering the three kinds of cuneiform language: Old Persian, Elamite, and Akkadian. ${ }^{20}$ Equally important is that DB is the longest inscription ever left by the Achaemenid Persians, ${ }^{21}$ thus providing important philological and historical information for Old Persian (OP) and its contemporaneous languages: Achaemenid Elamite (AE), Achaemenid Akkadian (AA), and Official Aramaic (OfA). ${ }^{22}$

19 The name Bisitun is not used by modern Iranians. This name was borrowed by H. C. Rawlinson from the Arabic geographer Yāqūt, who mentioned this site. The earliest known name of this mountain was given by Diodoros (Diodorus Siculus 2.13.1), who called it hóros ... Bagístanon. Its modern name Bisitun 'wiithout columns' is a result of folk etymology of Mediaeval Persian Bahistun 'with good columns'.

${ }^{20}$ The initial studies on the Bisitun inscription were about the decipherment of three different kinds of cuneiform writing. The history of scholarship on its decipherment is found in Booth (1982), Budge (1925), Pallis (1956), A short version is found in Kent \& Lecoq (1998).

${ }^{21}$ Old Persian text has 414 lines in four columns, Achamenid Elamite text has 260 lines in three columns, and Achaemenid Akkadian has 112 lines in one wide column.

22 Throughout this study I will use the abbreviations, AE, AA, OfA, and OP for Achaemenid Elamite, Achaemenid Akkadian, Official Aramaic, and Old Persian, the languages involved in the Bisitun inscription. 
In the sixth century B.C.E. King Darius, king of the then-illiterate Persians, subjected the peoples from the Nile to the Indus. ${ }^{23}$ Old Persian, the language of the ruling Persian class, did not spread beyond the Zagros mountain because the rapidity of his empire's expansion outstripped the speed of its diffusion and intelligibility among the provinces of his vast empire. Furthermore, Old Persian script, newly created during the time of King Darius, was used only for special declarations, edicts, and proclamations of the king.

Therefore, King Darius was forced to employ the contemporaneous languages of the ancient Near East for the record of his empire. For effective diplomatic communication among the provinces of the empire, Aramaic, a non-Iranian language, as a lingua franca, was chosen. It was a natural choice and a practical one: Aramaic was already widely spoken in the Levant, Egypt, and Western Iran and its alphabetic script was much easier to learn and write than the complicated Elamite or Akkadian cuneiform.

Elamite, however, became the language within the central administration in Susa, the most important city of Elam, continued to play a vital role in the bookkeeping of the administrative archives.

The peculiar linguistic situation of Achaemenid Persia encouraged multilingualism from the very beginning of its history. For the first time in the long history of the ancient Near East multilingual texts $^{24}$ in inscriptions became the norm, not the exception. ${ }^{25}$ Most Achaemenid inscriptions were trilingual: Old Persian, Elamite, and

${ }^{23}$ Two inscriptions (one from Persepolis (Darius Persepolish 5-8) and other from Hamadan (Darius Hamadan 4-6)) describe his vast empire: hacā Sakaibiš tayaiy para Sudgam amata yātā à kūta hacā Hindauv amata yātāa Spard̄̄ 'from the Scythians who are beyond Sogdiana, as far as to Nubia, from India as far as Lydia'.

24 Campanile (1988) draws up two criteria for the definition of bilingual text: 1) it must be an identical text in two versions in different languages; 2) it must show clear indication of simultaneousness on the level of its physical origin, which is located on the same object.

25 Although multilingualism has been a powerful fact of life in ancient Near East from the very beginning of its literary history, actual multilingual texts according to the definition given above, are very rare. See more in Galter (1995). 


\section{Akkadian. $^{26}$}

Therefore, when King Darius commissioned an inscription relating his military exploits, to be inscribed on the cliff of Mt. Bisitun, he had to employ bilingual or multilingual scribes who could translate his spoken Old Persian into Elamite, the administrative language, and Aramaic, the chancery language, because there was no Old Persian writing system at the time of the initial stage of its engraving.

Consequently, DB was not originally intended as a trilingual text. When King Darius spoke his res gestae in Old Persian, the bilingual scribe(s), perhaps a bilingual Elamite, translated it into Elamite. The Elamite version (DBa, the caption of King Darius and then AE DB to the right side of the relief) was engraved initially on the rock of Mt. Bisitun. Then, the Akkadian version, corresponding exactly to the Elamite version in its section divisions, was added to the left side of the relief. At the time of the Akkadian version composition, the bilingual scribe(s), perhaps a bilingual Babylonian, added new pieces of information to the res gestae: he added statistics of the number of casualties and captives, substituted Semitic month names for Iranian month names, and employed Median forms of geographic names instead of Old Persian forms.

It was only in the final stage that an Old Persian version was added below the relief to the existing two previous versions. The OP version contains editorial changes, different from both of the two previous versions: arrangement of res gestae according to battles, not campaigns, minor changes of contents, and the addition of OP DB \#70, which is the report about the creation of a new OP script and its dissemination into the provinces of the Achaemenid Persian empire. True to the words of King Darius in OP DB \#70, four fragments of DB were found in the empire provinces: two in Akkadian from Babylon, one in Aramaic in Elephantine, Egypt, and the other in Aramaic in Saqqara in Egypt.

${ }^{26}$ We have only four unilingual Akkadian and one Elamite texts as well as four bilingual Elamite-Old Persian and five Akkadian-Old Persian inscriptions so far. 


\section{Conclusion}

The major legacy of the Aramean civilization was its language and script. In these areas, the Arameans had an extraordinary impact on the Near East, well beyond their political perimeter. Aramaic was the most widely spoken language in Syria and Upper Mesopotamia during the first centuries of the first millennium. Aramaic was used by the conquering Assyrians as a language of administration communication, and following them by the Babylonian and Persian empires, which ruled from India to Ethiopia, and employed Aramaic as the official language. During the Achaemenid Persian Empire, they chose Aramaic for effective diplomatic communication among the provinces of the empire, which was a non-Iranian language, as a lingua franca, was chosen. It was a natural choice and a practical one: Aramaic was already widely spoken in the Levant, Egypt, and Western Iran and its alphabetic script was much easier to learn and write than the complicated Elamite or Akkadian cuneiform. For this period, then (about 700-320 B.C.E.), Aramaic held a position similar to that occupied by English today. The most important documents of this period are numerous papyri from Egypt and Palestine.

\section{References}

Beyer, K. 1986. The Aramaic Language. Translated by I. Healey. Göttingen: Vandelhoeck \& Ruprecht.

Biran, A \& J. Naveh. 1993. An Aramaic Stele Fragment from Tell Dan. Israel Exploration Journal 43, 81-98.

Booth, A. 1902. The Discovery and Decipherment of the Trilingual Cuneiform Inscriptions. London, New York, \& Bombay: Longmans.

Bordreuil, P. 1973. Une Tablette Araméen Inédite des 635 av. J.-C. Semitica $95-112$.

Budge, E. 1925. The Rise and Progress of Assyriology. London: Martin Hopkinton.

Caquot, A. 1971. Une Inscription Araméenne D'époque Assyrienne. Hommages à André Dupont-Sommer 9-16. Paris: Gallimard. 
Campanile, E. 1988. Per una Definizione del Testo Epigrafico Bilingue. Testi Linguisti 13, 17-8.

Cooper, J. 1973. Sumerian and Akkadian in Sumer and Akkad. Orientalia 42, 239-46.

Contini, R. 1986. I Documenti Aramaici del L'egitto Persiano e Tolemaico. Rivista Biblica 34, 73-109.

Emery, W. 1971. Archaic Egypt: Culture and Civilization in Egypt Five Thousand Years Ago. London: Penguin Books.

Fales, F. 1986. Aramaic Epigraphs on Clay Tablets of the Neo-Assyrian Period. Rome.

Fitzmeyer, J. 1979. The Phrase of the Aramaic Language. In J. Fitzmyer (ed.), A Wandering Aramean: Collected Aramaic Essays 57-84. Cambridge: Cambridge University Press.

Folmer, M. 1995. The Aramaic Langauge in the Achaemenid Period: A Study in Linguistic Variation, Orientalia Lovanensia Analecta. Leuven: Peeters Press.

Galter, H. 1995. Cuneiform Bilingual Royal Inscriptions. Israelite Oriental Society 14, 25-50.

Ginsberg, H. 1933-4. Aramaic Dialect Problems. American Journal of the Semitic Languages 50, 1-9.

Greenfield, J. 1978. The Dialects of Early Aramaic. Journal of the Near Eastern Studies 37, 93-99.

1978. Aramaic and its Dialects. In H. Paper (ed.), Jewish Languages: Theme and Variations 29-43. Cambridge: Cambridge University Press. .1982. p. 471

Holm, J. 1988. Pidgins and Creoles 1: Theory and Structure. Cambridge: Cambridge University Press.

Jacobsen, T. 1969. Some Sumerian City-Names. Journal of Cuneiform Studies 21, 100-3.

Kaufman, S. 1974 The Akkadian Influence on Aramaic. Chicago, IL: University of Chicago Press.

Kent, R. 1953. Old Persian Grammar. New Haven, MA: American Oriental Society.

Krealing, E. 1953. The Brooklyn Museum Aramaic Papyri: New Documents of the Fifth Century B.C. from the Jewish Colony at Elephantine. New Haven, MA: American Oriental Society.

Lansberger, B. 1974. Three Essays on the Sumerians. Translated by. M. Ellis. MANE 1/2. Los Angels.

Lecoq, P. 1998. Les Inscriptions de la Perse Achéménid. Paris: Gallimard. Lieberman, S. 1977. Sumerian Loanwords in OId Babylonian, Harvard 
20 Aramaic as a Lingua Franca During the Persian Empire (538-333 B.C.E.)

Semitic Series 22. Cambridge, MA: Harvard University Press.

LipiĎsk, E, 1990. Araméen D’empire. Le Language dans L'antiquité 94. Leuven.

Malamat, A. 1973. The Arameans. In D. Wiseman (ed.), Peoples of Old Testament Times 134-155. Oxford: Cambridge University Press.

Markwart J, 1927. NP Ā dina Freitag. Ungarische Jahrbücher.

Naveh, J. 1973. The Aramaic Ostraca. In Y. Aharoni (ed.), Beer-Sheba I, Excavations at Tell Beer-Sheba (1969-1971) 79-82. Paris: Seasons.

Naveh, J. \& J. Greenfield 1984. Hebrew and Aramaic in the Persian Period. In W. Davies \& L. Finkelstein (eds.), Cambridge History of Judaism 1, 115. Cambridge: Cambridge University Press.

Pallis, S. 1956. The Antiquity of Iraq: A Handbook of Assyriology. Copenhagen: Ejnar Munksgaard.

Pritchard, J. 1969. Ancient Near Eastern Texts Relating to the Old Testament. Princeton, NJ: Princeton University Press.

Starky, J. 1960. Une Tablette Araméen de L'an 34 de Nabuchodonosor. Syria 37, 99-115.

Tadmor, C. 1982. The Aramaization of Assyria: Aspects of Western Impackt. In H. Nissen \& J. Renger (eds.), Mesopotamien und Seiner Nachbar, Akten des XXV RAI 45. Jerusalem.

Teyssier, P. 1959. La Langue de Gil Vincente. Paris: Klincksieck.

Wesselius, J.W. 1985. A Document Concerning the Substance of a Mother by her Sons. AION 45, 506-508.

Zyhlar, E. 1932. Ursrpung und Sprachcharacter des Altägpytischen. Zeitschrift für Eingeborenen-Sprachen 23, 25-45. 